\title{
ВІДГОДІВЕЛЬНІ ЯКОСТІ СВИНЕЙ ІРЛАНДСЬКОГО ПОХОДЖЕННЯ ЗА РІЗНОГО ТИПУ ГОДІВЛІ
}

\author{
Михалко Олександр Григорович \\ аспірант спеціальність 204 ТВППТ \\ Сумський національний аграрний університет \\ ORCID: 0000-0002-0736-2296/ G-2305-2018 \\ Email: snau.cz@ukr.net
}

3 метою дослідження впливу рідкого та сухого типів годівлі на відгодівельні якості свиней проведено дослід з поголів'ям двох груп, утримуваних в цехах відгодівлі свинарського комплексу розташованого в умовах Центрального степу України. За результатами проведеного досліду в даній статті описано та порівняно залежність відгодівельних якостей свиней ірландської селекції від використання різних типів годівлі. На початку періоду поголів'я поставлене на відгодівлю різними раціонами не відрізнялось за середньою живою масою, проте, в кінці 106-ти денного терміну утримання тварини, що споживали рідкі корми, вірогідно перевищили своїх однолітків, яким давали попередньо не зволожені кормосуміші на 8,8 ке або 7,1\% (p<0,001). Також встановлено, що тварини утримувані за споживання рідкого корму мали на 8,3 кट або 8,5\% ( $<<0,001)$ вищі абсолютні прирости порівняно із аналогами, які споживали сухий корм. Доведено, що дослідні свині, вирощувані за відгодівлі рідкими кормами мали вірогідне перевищення за показником середньодобових приростів над вирощеними за використання сухих кормів на 0,078 ка або 8,5\% (p<0,001). Виявлено достовірно вищі відносні прирости у поголів'я на рідкому раціоні ніж у аналогів, утримуваних на сухих сумішах на 3,2\% $(p<0,001)$ впродовж усього періоду відгодівлі. Необхідно відмітити, що наслідком споживання сухих кормів стало достовірне відставання дослідних свиней від аналогів, які щоденно їли рідкий корм за показником віку досягнення маси 100 ке на 7,8 днів або 5,2\%. Проте, різні раціони не мали вірогідного впливу на витрати корму на 1 ке приросту. Індекс комплексної оцінки відгодівельних якостей показав вищу бальну оцінку на 5,8 балів або 16,1\% у свиней вирощених за рідкого типу годівлі.

Ключові слова: відгодівельні якості, тип годівлі, відгодівля свиней, рідкі та сухі корми

DOI: https://doi.org/10.32845/bsnau.lvst.2020.3.9

Годівля свиней - важливий елемент технології виробництва продукції свинини в умовах індустріальних комплексів. Відгодівля свиней $є$ основною фазою виробництва свинини, на яку припадає більше $70 \%$ виробничих витрат. Вибір системи годівлі тварин впливає на показники середньодобових приростів, конверсії корму, собівартості 1 кг живої маси, а також на прямо пов'язані до останніх показники чистого прибутку та рентабельності підприємства. Залежно від співвідношення сухого корму та води виділяють три типи кормів: рідкі, вологі та комбіновані [6,].

Як сухий так і рідкий типи годівлі мають свої переваги та недоліки. Вони однаково можуть бути як ефективними, так і не ефективними за різних техніко-технологічних рішень та за використання різних генотипів тварин чи за різного їх походження.

Деякі дослідники стверджують, що рідкий корм краще задовольняє фізіологічні потреби свиней, дає можливість забезпечити поступову заміну раціонів і ферментацію корму. При цьому рідкий корм вважається більш смачнішим для свиней, ніж сухий, що збільшує його споживання й відповідно прирости. Водночас, система рідкої годівлі вимагає чіткої дисципліни операторів, які повинні постійно стежити за роботою системи кормо роздавання та за якістю корму. 3 іншого боку, $€$ судження, що суха годівля вимагає менших витрат на обладнання та обслуговування, а корм за санітарно-гігієнічними властивостями стабільніший і може довше зберігатися [8].

Проте В.М. Нечмілов [4] у своїх дослідженнях не встановив чіткої залежності між показниками конверсії корму за сухого та рідкого типу годівлі в розрізі вагових категорій при відгодівлі свиней.

За результатами вивчення впливу типу годівлі на ефективність відгодівлі кнурів за різного способу кастрації,

здійсненими М.Г. Поводом [5], комплексний індекс відгодівельних якостей був на 23,9\% вищим у тварин, що споживали саме вологий корм.

В.М. Волощук [2] вважає, що рідкий тип годівлі є найоптимальнішим з точки зору фізіологічного засвоєння організмом свиней, а Г.С. Походня вказує на найвищу пріоритетність вологого корму на відміну від сухого при здійсненні вибору тваринами в експериментальних умовах [7].

На думку Byung J. Chae [12], за використання вологого типу відгодівлі свиней не спостерігалось більш раннє досягнення забійної маси порівняно із тваринами, що споживали сухі корми.

Досліджуючи процес відгодівлі свиней R. Braude та J.G. Rowell [10] стверджують, що свині за сухого типу годівлі мали суттєво нижчий середньодобовий приріст та засвоєння кормів, а середня довжина туші була дещо меншою. Одночасно достовірної залежності між товщиною шпику та типом годівлі виявлено не було.

H.W. Gonyou та Z. Lou [13] продемонстрували, що свині, які годуються рідким кормами, зазвичай мають більше середньодобове споживання корму та вищий темп росту, ніж ті, що споживають виключно сухий корм. Проте, їх дослідження не показали достовірної відмінності між показниками конверсії корму у різних груп тварин, яких утримували за альтернативних типів годівлі.

Подібний висновок, підтверджується N. Walker, A. Maton i J. Daeleman [20, 17], які встановили достовірне підвищення приросту маси тварин внаслідок саме більшого споживання корму.

Аналогічних результатів дійшли Т. Jensen та X. Averos [15, 9], довівши, що свині, яких вирощують за використання рідкого типу годівлі, мають коротший час відвідування годівниці, вищі показники прийому корму за один раз, 
набирають більшу вагу порівняно із тваринами, що вирощуються на сухому типі годівлі. D Hurst [14], було відмічено, що рідке годування покращувало середньодобовий приріст живої маси свиней $(p<0,05)$ та швидкість росту нежирної тканини у тварин, однак, на коефріцієнт конверсії корму це не впливало.

Згідно P. Lawlor [16] за рідкого типу відгодівлі у свиней збільшувалось споживання кількості корму та підвищувалась забійна маса тварин, але при цьому погіршувалась конверсія корму порівняно із способом годівлі сухими кормами. В той же час, за використання сухого типу годівлі конверсія корму була достовірно вищою.

I. Campani [11] говорить, що технологія використання вологого корму у порівнянні із сухим кормом покращує швидкість росту та конверсії корму, однак, потребує додаткового доопрацювання в мікробіологічному аспекті.

Вивчаючи відмінності різних типів годівлі свиней F.M. O'Meara та G.E. Gardiner [19], встановили, що кількість молочнокислих бактерій та дріжджів була значно більшою для рідких кормів, ніж у кормах сухих раціонів. А також були виявлені докази деградації лізину в рідкому раціоні, хоча це не впливало на ріст свиней.

3 точки зору добробуту тварин M. Zoric [18] рекомендує сухий корм, оскільки поведінка свиней у групах, де здійснювалась годівля рідкими кормами, відрізнялась вищою агресивністю, особливо безпосередньо перед самою подачею в годівниці.
Н.П. Грищенко [3] у своїх дослідженнях відзначає, що при підвищенні вологості корму до 83\% погіршується використання азоту на 6,6\%, таким чином, з точки зору використання азоту корму, згодовування кормів у рідкому вигляді на її думку менш доцільно. При цьому консистенція корму, як правило не впливає на перетравність поживних речовин.

Враховуючи суперечність даних різних дослідників в даному напрямку, та вплив генотипових і паратипових факторів при використанні свиней ірландської селекції в умовах Степу України, підвищення ефективності виробництва свинини шляхом удосконалення існуючих та розробки нових технологічних прийомів відгодівлі тварин $є$ актуальним питанням сучасного інтенсивного свинарства.

Метою роботи $€$ пошук шляхів удосконалення технологічних прийомів відгодівлі молодняку свиней з урахуванням потенційних резервів їх підвищення та урахуванням виявлених проблем.

Матеріали та методи досліджень. Для вирішення поставленої задачі був поставлений дослід з метою вивчення відгодівельних якостей свиней ірландського походження, що утримувались двома групами по 210 голів впродовж 106 днів в цехах відгодівлі №1 та №3 підприємства ТОВ НВП «Глобинський свинокомплекс», при використанні різних типів відгодівлі, але за інших рівних умов утримання впродовж вказаного часу (табл. 1).

\section{Група тварин}

I (контрольна)

II (дослідна)

$$
\text { Кількість голів в групі }
$$

\section{Схема досліду}

$$
\text { Вік при постановці }
$$

Таблиця 1

\section{Тип годівлі}

Рідкий

Сухий

I (контрольна) група включала свиней у віці 70 днів відің включала рідкі кормові суміші на основі повнораціонних комбібраних за однакової середньої живої маси. Годівля свиней кормів власного виробництва.

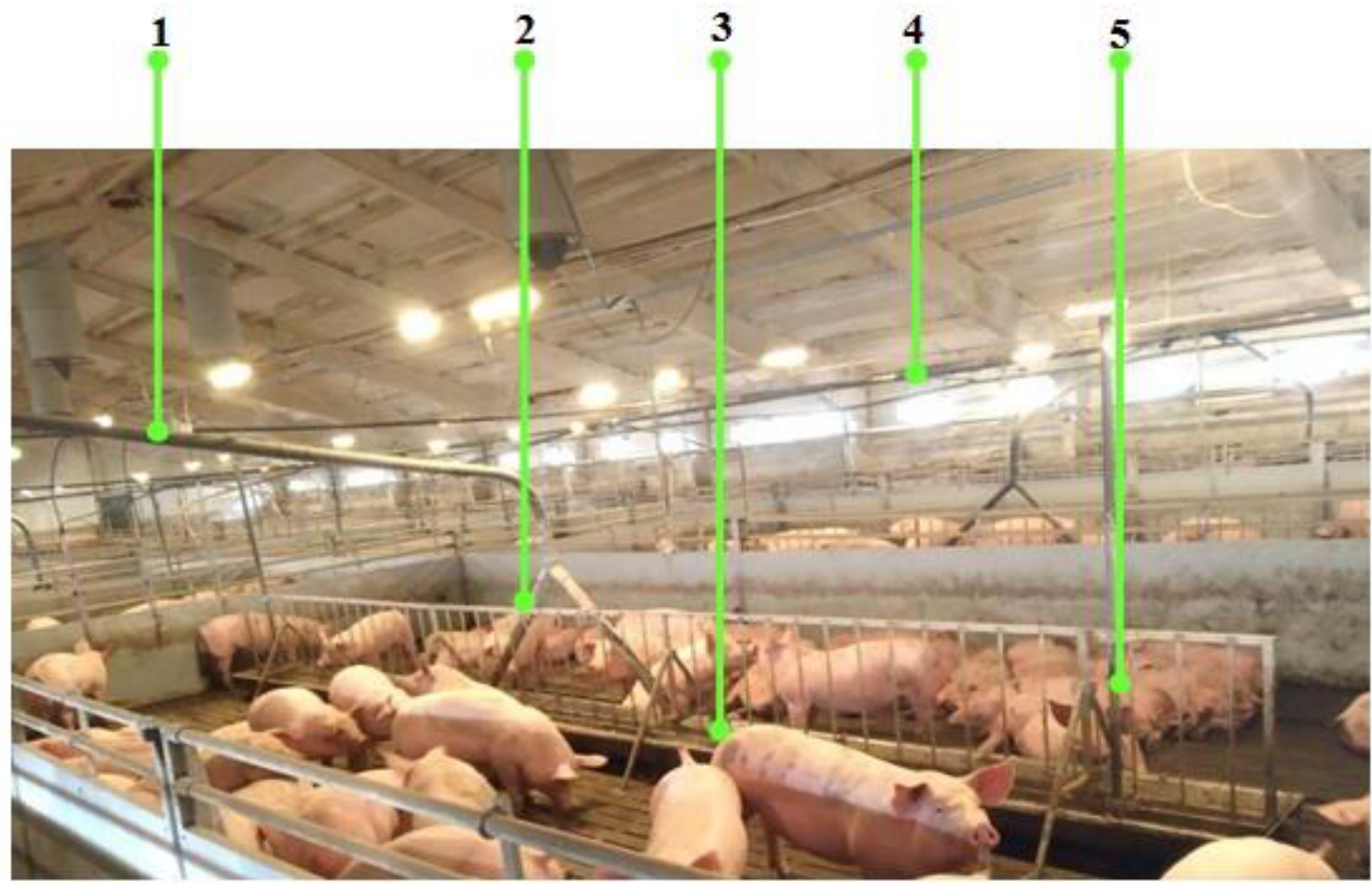

Puc. 1 Система подачі рідкого корму Veda 
1 - трубопровід, 2 - розподільчий трубопровід, 3 - годівниця, 4 - магістральний трубопровід,

5 - індикатор наповнюваності

При цьому приготування рідкої суміші та їі роздача про на повністю щілинній підлозі з розрахунку 0,75 м² на 1 голову. водилась за допомогою кормової кухні австрійської фірми Veda. Системи напування, гноєвидалення та мікроклімату приміСвині контрольної групи під час відгодівлі споживали рідкий корм у співвідношенні 1 частина повнораціонного збалансова ного корму до 3-х частин води. Корм готувався в ємностях кор мокухні шляхом додавання сухої ії частини до підкисленої води Ретельно перемішана фракція подавалась по системі трубоп роводів (рис.1, п. 1, 2, 4) до годівниці (рис. 1, п. 3) 10-12 разів на о добу. Система годівлі обладнана датчиками наповненості годі вниці (рис.1, п. 5), які спрацьовують при неповному поїданн корму тваринами шляхом пропуску чергової годівлі. Фронт годі влі був 0,18 м на 1 голову. Облік кормів на кожний станок про водився за допомогою програми кормової кухні Veda

У II (дослідну групу) було включено поголів'я ідентичне за віком і середньою живою масою поставлене на відгодівлю сухим кормом. Тварин утримували в станках по 50 голів щень булі аналогічні контрольній групі. Годівля тварин здійснювалась сухими повнораціонними комбікормами зі зволоженням їх в кормових автоматах американської фірми Hog Slat (рис. 2, п. 3), транспортування корму до яких здійснювалось із бункерів-накопичувачів за допомогою ланцюгово-шайбового транспортера (рис. 2, п. 2) та опусків (рис. 2, п.1). Корм до бункера кормового автомату потрапляв у сухому вигляді, де був вручну зважений для кожного станка. 3 метою обліку спожитого корму в усіх дослідних станках було перекрито шибери подачі корму, а його подавання в годівниці відбувалось через зважування вручну. Зволоження корму відбувалося за допомогою зрошувачів розташованих в жолобі кормового автомату. Фронт годівлі був 0,1 м на одну голову.

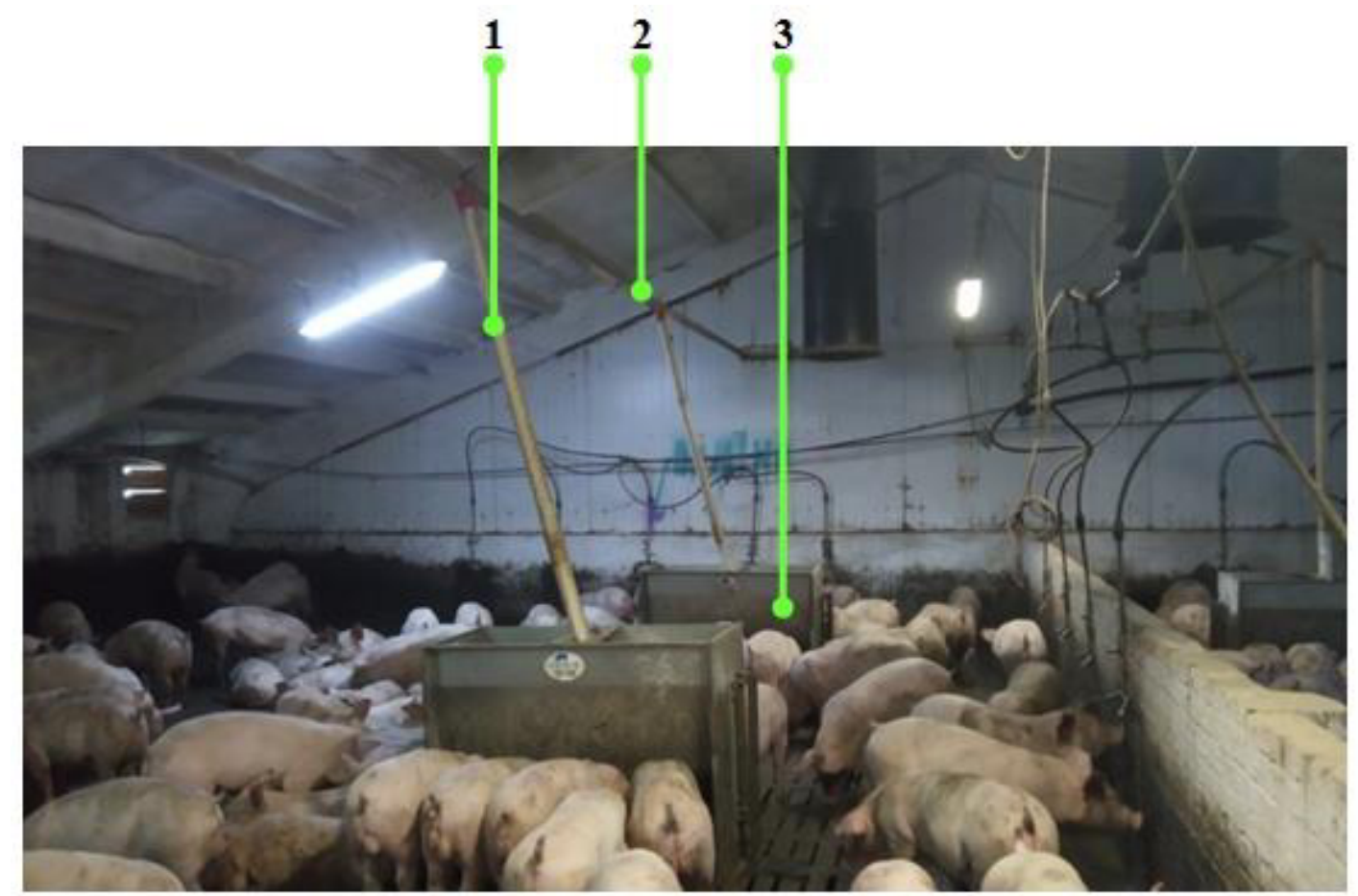

Puc. 2 Система подачі сухого корму

1 - опуск, 2 - ланцюгово-шайбовий транспортер, 3 - кормовий автомат

Обидві групи свиней були отримані від помісних свиноматок ірландського ландраса та ірландського йоркшира і кнурів синтетичної лінії Maxgro. Їх утримання в підсисний період та період дорощування було аналогічним.

На початку та по закінченню терміну відгодівлі всі тварини були індивідуально зважені, на основі чого було проведено розрахунки інтенсивності росту, середньодобового споживання та оплати корму.

Для оцінки відгодівельних характеристик дослідних свиней було використано комплексний індекс відгодівельних якостей за формулою М.Д. Березовського [1]:

$$
I=\frac{\mathrm{A}^{2}}{\mathrm{~B} * C}
$$

де: A - валовий приріст за період відгодівлі, кг;

В - кількість діб відгодівлі;

C - витрати корму на 1 кг приросту.

Результати досліду були обраховані біометрично за допомогою прикладних програм Microsoft Office Excel.

Результати досліджень. Згідно з даними експерименту, наведеними у табл. 2, виявлено відмінності за показниками відгодівельних якостей тварин різних піддослідних груп. 
Відгодівельні показники свиней за різного типу годівлі, (n=210)

\begin{tabular}{|l|c|c|}
\hline \multicolumn{1}{|c|}{ Показник } & \multicolumn{2}{|c|}{ Тип годівлі } \\
\cline { 2 - 3 } & $\begin{array}{c}\text { I контрольна група } \\
\text { (рідкий тип годівлі) }\end{array}$ & $\begin{array}{c}\text { ІІ дослідна група } \\
\text { (сухий тип годівлі) }\end{array}$ \\
\hline Середня маса при постановці на відгодівлю, кг & $26,4 \pm 0,27$ & $26,0 \pm 0,24$ \\
\hline Середня маса при знятті з відгодівлі, кг & $125,0 \pm 0,80^{* * *}$ & $116,2 \pm 0,76$ \\
\hline Кількість днів на відгодівлі, діб & 106 & 106 \\
\hline Абсолютний приріст, кг & $98,6 \pm 0,77^{* * *}$ & $90,2 \pm 0,69$ \\
\hline Середньодобовий приріст, г & $929,7 \pm 7,30^{* * *}$ & $850,9 \pm 7,10$ \\
\hline Відносний приріст, \% & $130,1 \pm 0,61^{* * *}$ & $126,8 \pm 0,59$ \\
\hline Витрати корму на 1 кг приросту (конверсія), кг & 2,51 & 2,50 \\
\hline Вік досягнення маси 100 кг, діб & $151,1 \pm 0,93$ & $160,0 \pm 0,88^{* * *}$ \\
\hline Індекс відгодівельних якостей, балів & 36,58 & 30,70 \\
\hline
\end{tabular}

Примітки: * $P>0,95 ;{ }^{*} P>0,99$

При постановці на відгодівлю достовірної різниці між тваринами не встановлено. Однак, при знятті з відгодівлі свині, які споживали рідкі корми вірогідно перевищували однолітків, утримуваних за сухого типу годівлі на 8,8 кг або 7,1\% $(p<0,001)$.

Поголів'я контрольної групи випереджало за показниками абсолюного приросту аналогів дослідної на 8,3 кг або 8,5\% (p<0,001).

Різниця показників середньодобового приросту між тваринами обох груп набула достовірного перевищення на користь свиней утримуваних за рідкого типу годівлі на 78,8 г або 8,5\% (p<0,001).

Аналіз відносних приростів показав, що кращими вони були також у свиней, які споживали рідкий корм та вірогідно перевищували тварин дослідної групи за цим показником впродовж досліджуваного періоду на 3,2\% ( $<<0,01)$.

Таким чином, вивчення інтенсивності росту експериментального поголів'я впродовж досліджуваного періоду виявило достовірну перевагу за абсолютними, середньодобовими та відносними приростам тварин, які відгодовувались за рідкого раціону порівняно з їх аналогами, котрі споживали сухий корм. Встановлено тенденцію до перевищення тварин контрольної групи над тваринами дослідної за показником конверсії корму - на 0,01 кг або 0,2\%. Також, свині, що отримували рідкий корм достовірно раніше досягали маси 100 кг - на 7,8 днів або 5,2\%.

За комплексом відгодівельних якостей, розрахованих з допомогою оціночного індексу, тварини які споживали сухий корм поступались аналогам за рідкого типу годівлі на 5,8 балів або 16,1\%.

Існування виявленої нами тенденції до зростання показників відгодівельних якостей свиней за рідкого типу годівлі підтверджується дослідженнями В.М. Волощука [2], T. Jensen i X. Averos [9, 15] та R. Braude i J.G. Rowell [10].

Підтверджене нами достовірно більш раннє досягнення забійної маси в 100 кг тваринами, що споживають рідкі корми співпадає з аналогічними висновками В.J. Chae [12].

Однак, знайдена відсутність достовірної різниці за показником конверсії корму між тваринами на різних типах годівлі суперечить як висновкам I. Campani [11], який наголошує на факті вірогідно більш низьких витрат корму на 1 кг приросту за годівлі свиней рідкими кормами, так і твердженням Р. Lawlor [16], який наголошує, що навпаки - конверсія корму тільки погіршується за використання рідкого типу годівлі.

В той же час, виявлене перевищення комплексного індексу відгодівельних якостей тварин на рідкому раціоні над тваринами, що відгодувались за використання сухих сумішей на 16,1\% співпадає із результатами М.Г. Повода, [5], який по завершенні свого досліду зафіксував перевищення цього показника на 23,9\% по даному індексу тварин за вологого типу годівлі.

Висновки. 1. Свині ірландського походження в умовах Степу України під час відгодівлі демонструють достовірно вищі темпи росту за споживання рідкого корму, досягаючи при цьому живої маси 100 кг на 7,8 днів раніше, ніж за використання сухого типу годівлі.

2. За час відгодівлі свині, яким давали сухі корми, мали достовірно вищу живу масу на 8,8 кг (p<0,001) ніж свині, що утримувались на рідкому типі годівлі.

3. Не виявлено достовірної різниці за показником конверсії корму між тваринами на різних за вологістю типах раціонів, що вказує на необхідність подальших досліджень в бік пошуку резервів зниження витрат корму на 1 кг приросту як для способу відгодівлі за використання рідких кормів, так і для способу відгодівлі сухими кормами.

\section{Список використаної літератури:}

1. Березовский Н. Д., Почерняев Ф. К., Коротков В. А. Методика моделирования индексов для использования их в селекции свиней. Методы улучшения процессов селекции, разведения и воспроизводства свиней (методические указания). М., 1986. С. 3-14.

2. Волощук О. В., Обґрунтування використання кнурів-плідників французької селекції за промислового схрещування. Дисертація кандидата с.-е. наук: Волощука О. В. Київ, 2019. 47 с.

3. Грищенко Н. П., Удосконалення технологічних прийомів відгодівлі молодняку свиней. Дисертація кандидата с.-2. наук: Грищенко Н. П. Київ, 2014. 142 с.

4. Нечмілов В. М., Повод М. Г. Відгодівельна продуктивність свиней за різних термінів дорощування та використання сухого і рідкого типів годівлі. Вісник Сумського національного аграрного університету. Серія «Тваринництво», 2018, Вип. 7 (35), c. 122-134. 
5. Повод М. Г., Кравченко О. І., Нечмілов В. М., Кліндухова І. М. Відгодівельні якості хірургічних та імунологічних кастратів за різного типу годівлі та передзабійної живої маси. Вісник Сумського наиіонального аграрного університету. Серія «Тваринництво», 2018, Вип. 7 (35), с. 135-139.

6. Походня Г. С. Промышленное свиноводство. Белгород: Крестьянское дело, 2011. 483 с

7. Походня Г. С. Теория и практика воспроизводства и выращивания свиней. Москва: Агропромиздат, 1990. с. 270.

8. Практичні поради для оптимізації годівлі та зниження інших виробничих витрат. Прибуткове свинарство. 2017. Вип. 1(37), Електронний ресурс URL: http://pigua.info/uk/post/prakticni-poradi-dla-optimizacii-godivli-ta-znizenna-insih-virobnicihvitrat_Дата звернення: 11.12 .2020 p.

9. Averós, X. L., Brossard, J., Dourmad, Y., de Greef, K. H., Edwards, S. A., and Meunier-Salaün, M.C., 2012. Meta-analysis on the effects of the physical environment, animal traits, feeder and feed characteristics on the feeding behavior and performance of growing-finishing pigs. Animal, issue 8, pp. 275-1289. doi:10.1017/S1751731112000328

10. Braude, R. and Rowell, J., 1967. Comparison of dry and wet feeding of growing pigs. The Journal of Agricultural Science, issue 68, Vol 3, pp. 325-330. doi:10.1017/S0021859600012818

11. Campani, I., 2010. Dilution in liquid feed. Nutrition. URL: https://www.pig333.com/articles/dilution-in-liquid-feed_3110/ Request date: 09.01.2020 p. $81-96$

12. Chae, B. J., 2000. Impacts of wet feeding of diets on growth and carcass traits in pigs. J. Appl. Anim. Res., issue 17, pp.

https://www.tandfonline.com/doi/pdf/10.1080/09712119.2000.9706293

13. Gonyou, H. W. and Lou, Z., 2000. Effects of eating space and availability of water in feeders on productivity and eating behavior of grower/finisher pigs. J. Anim., Sci. issue 78, pp.865-870. doi:10.2527/2000.784865x

14. Hurst, D., Clarke, L. and Lean, I. J., 2008. Animal, issue 2, Vol. 9, pp. 1297-1302.

15. Jensen, T., Nielsen, C. K., Vinther, J. and D'Eath, R. B., 2012. The effect of space allowance for finishing pigs on productivity and pen hygiene. Livest. Sci., issue 149, pp. 33-40. doi: 10.1016/.jlivsci.2012.06.018

16. Lawlor, P. and O' Meara, F., 2018. Comparison of dry, wet/dry and wet feeding for finisher pigs. Teagasc Agriculture and Food Development Authority report, URL: https://www.teagasc.ie/publications/2018/comparison-of-dry-wetdry-and-wet-feeding-forfinisher-pigs.php Request date: 09.01.2020.

17. Maton, A., and Daelemans J., 1992. Third comparative study viz. the circular wet-feeder versus the dry-feed hopper for ad libitum feeding and general conclusions concerning wet feeding versus dry feeding of finishing pigs. Rev. Agr. (Brussels), issue 45, pp. 531-539.

18. Zoric, M., Johansson, S.E. and Wallgren, P., 2015. Behaviour of fattening pigs fed with liquid feed and dry feed. Porc Health Manag, issue 1, Vol. 14. https://doi.org/10.1186/s40813-015-0009-7

19. O'Meara, F. M., Gardiner, G. E., O'Doherty, J. V. and Lawlor, P. G., 2020. The effect of feed form and delivery method on feed microbiology and growth performance in grow-finisher pigs. Journal of Animal Science. issue 98. Vol. 3: skaa021. https://doi.org/10.1093/jas/skaa021

20. Walker, N., 1990. The influence of hopper-type feeders on performance of pigs. Pig News Inf, issue 11, pp. 31-33.

\section{References:}

1.Berezovskiy, N. D., Pochernyaev, F. K. and Korotkov, V. A., 1986. Metodika modelirovaniya indeksov dlya ispolzovaniya in v selektsii sviney [Methodology for modeling indices for use in breeding pigs]. Metodyi uluchsheniya protsessov selektsii, razvedeniya i vosproizvodstva sviney (metodicheskie ukazaniya), pp. 3-14.

2.Voloshchuk, O. V., 2019. Obgruntuvannia vykorystannia knuriv-plidnykiv frantsuzkoi selektsii za promyslovoho skhreshchuvannia [Rationale for the use of breeding boars of French selection in industrial crossbreeding]. Abstract of Ph.D. dissertation. Kyiv.

3.Hryshchenko N. P., 2014. Udoskonalennia tekhnolohichnykh pryiomiv vidhodivli molodniaku svynei [Improvement of technological methods of fattening young pigs]. Abstract of Ph.D. dissertation. Kyiv.

4.Nechmilov, V. M., and Povod, M. H., 2018. Vidhodivelna produktyvnist svynei za riznykh terminiv doroshchuvannia ta vykorystannia sukhoho i ridkoho typiv hodivli [Fattening productivity of pigs at different terms of rearing and use of dry and liquid types of feeding.]. Visnyk Sumskoho natsionalnoho ahrarnoho universytetu. Seriia «Tvarynnytstvo», issue 7 (35), pp. 122-134.

5.Povod, M. H., Kravchenko, O. I., Nechmilov, V. M. and Klindukhova, I. M., 2018. Vidhodivelni yakosti khirurhichnykh ta imunolohichnykh kastrativ za riznoho typu hodivli ta peredzabiinoi zhyvoi masy [Feeding qualities of surgical and immunological castrates for different types of feeding and pre-slaughter live weight]. Visnyk Sumskoho natsionalnoho ahrarnoho universytetu. Seriia "Tvarynnytstvo», issue 7 (35), pp. 135-139.

6.Pohodnya, G. S., 2011. Promyishlennoe svinovodstvo [Industrial pig breeding]. Belgorod: Krestyanskoe delo, p. 483.

7.Pohodnya, G. S., 1990. Teoriya i praktika vosproizvodstva i vyiraschivaniya sviney [Theory and practice of reproduction and breeding of pigs]. Moskva: Agropromizdat, p. 270

8.Praktychni porady dlia optymizatsii hodivli ta znyzhennia inshykh vyrobnychykh vytrat. Prybutkove svynarstvo. [Elektronnyi resurs]. URL: http://pigua.info/uk/post/prakticni-poradi-dla-optimizacii-godivli-ta-znizenna-insih-virobnicih-vitrat [datazvernennia 11.12.2020]

9.Averós, X. L., Brossard, J., Dourmad, Y., de Greef, K.H., Edwards, S.A., and Meunier-Salaün, M.C., 2012. Meta-analysis on the effects of the physical environment, animal traits, feeder and feed characteristics on the feeding behavior and performance of growing-finishing pigs. Animal, issue 8, pp. 275-1289. doi:10.1017/S1751731112000328 
10. Braude, R. and Rowell, J., 1967. Comparison of dry and wet feeding of growing pigs. The Journal of Agricultural Science, issue 68, Vol 3, pp. 325-330. doi:10.1017/S0021859600012818

11. Campani, I., 2010. Dilution in liquid feed. Nutrition. URL: https://www.pig333.com/articles/dilution-in-liquid-feed_3110/ Request date: 09.01.2020. 81-96.

12. Chae, B.J., 2000. Impacts of wet feeding of diets on growth and carcass traits in pigs. J. Appl. Anim. Res., issue 17, pp.

https://www.tandfonline.com/doi/pdf/10.1080/09712119.2000.9706293

13. Gonyou, H. W. and Lou, Z., 2000. Effects of eating space and availability of water in feeders on productivity and eating behavior of grower/finisher pigs. J. Anim. Sci., issue 78, pp.865-870. doi:10.2527/2000.784865x

14. Hurst, D., Clarke, L. and Lean, I.J., 2008. Animal, issue 2, Vol. 9, pp. 1297-1302.

15. Jensen, T., Nielsen, C. K., Vinther, J. and D'Eath, R. B., 2012. The effect of space allowance for finishing pigs on productivity and pen hygiene. Livest. Sci., issue 149, pp. 33-40. doi: $10.1016 /$ j.livsci.2012.06.018

16. Lawlor, P. and O' Meara, F., 2018. Comparison of dry, wet/dry and wet feeding for finisher pigs. Teagasc Agriculture and Food Development Authority report, URL: https://www.teagasc.ie/publications/2018/comparison-of-dry-wetdry-and-wet-feeding-forfinisher-pigs.php Request date: 09.01.2020.

17. Maton, A., and Daelemans J., 1992. Third comparative study viz. the circular wet-feeder versus the dry-feed hopper for ad libitum feeding and general conclusions concerning wet feeding versus dry feeding of finishing pigs. Rev. Agr. (Brussels), issue 45, pp. 531-539.

18. Zoric, M., Johansson, S. E. and Wallgren, P., 2015. Behaviour of fattening pigs fed with liquid feed and dry feed. Porc Health Manag, issue 1, Vol. 14 . https://doi.org/10.1186/s40813-015-0009-7

19. O'Meara, F. M., Gardiner, G.E., O'Doherty, J. V. and Lawlor, P. G., 2020. The effect of feed form and delivery method on feed microbiology and growth performance in grow-finisher pigs. Journal of Animal Science, issue 98. Vol. 3: skaa021. https://doi.org/10.1093/jas/skaa021

20. Walker, N., 1990. The influence of hopper-type feeders on performance of pigs. Pig News Inf, issue 11, pp. 31-33.

Mykhalko Oleksandr Hryhorovych, graduate student, Sumy National Agrarian University (Sumy, Ukraine)

Fattening qualities of Irish pigs origin at different types of feeding

In order to study the impact of liquid and dry types of feeding on the fattening qualities of pigs, an experiment was conducted with livestock of two groups kept in fattening shops of one pig complex located in the Southern steppe of Ukraine. According to the results of the experiment, this article describes and compares the dependence of fattening qualities of pigs of Irish selection on the use of different types of feeding. At the beginning of the period, the fattening stock did not differ in average live weight, but at the end of the 106-day retention period, the animals consuming liquid feed probably exceeded their peers, who were given unmoistened feed mixtures by $8,8 \mathrm{~kg}$ or $7,1 \%$ ( $p<0,001)$. It was also found that animals kept for liquid feed consumption had 8,3 $\mathrm{kg}$ or $8,5 \%$ ( $p<0,001)$ higher absolute gains compared to animals that consumed dry food. It was proved that experimental pigs reared for fattening with liquid feed had a probable increase in the average daily gain over those grown using dry feed by $0,078 \mathrm{~kg}$ or $8,5 \%$ ( $p<0,001)$. Significantly higher relative gains in livestock were found than in analogues kept on dry mixes by $3,2 \%(p<0,001)$ during the entire fattening period. It should be noted that the result of the consumption of dry feed was a significant lag of experimental pigs from analogues, who ate liquid feed daily according to the Age of reaching a weight of $100 \mathrm{~kg}$ by 7,8 days or $5,2 \%$. However, different diets did not have a significant effect on feed consumption per $1 \mathrm{~kg}$ of gain. The index of comprehensive assessment of fattening qualities showed a higher score of 5,8 points or $16,1 \%$ in pigs reared with liquid type of feeding.

Key words: fattening qualities, type of feeding, fattening of pigs, liquid and dry feed

Дата надходження до редакції: 26.10.2020 р. 